Marquette University

e-Publications@Marquette

Social and Cultural Sciences Faculty Research and

Publications

Social and Cultural Sciences, Department of

$2-1-2012$

Explaining Political Violence Against Civilians in Northern Ireland: A Contention-Oriented

Approach

Gregory M. Maney

Hofstra University

Michael A. McCarthy

Marquette University, michael.mccarthy@marquette.edu

Grace B. Yukich

Quinnipiac University

Published version. Mobilization: An International Journal, Vol. 17, No. 1 (February 2012): 27-48.

Publisher Link. (C) 2012 San Diego State University. Used with permission. 


\title{
EXPLAINING POLITICAL VIOLENCE AGAINST CIVILIANS IN NORTHERN IRELAND: A CONTENTION-ORIENTED APPROACH*
}

\author{
Gregory M. Maney, Michael A. McCarthy, and Grace B. Yukich ${ }^{\dagger}$
}

\begin{abstract}
In contrast to prevalent theories of terrorism, this study develops a contention-oriented approach where levels and forms of political violence against civilians depend upon: (1) the strategies of combatants; (2) the means of contention; (3) the locations of allies and opponents; (4) the collective identities of combatants; and (5) the dynamics of contention, including whether or not representatives of paramilitary organizations are included in formal peace processes. Quantitative analyses of a multi-source database of civilian deaths taking place in Northern Ireland between 1966 and 2006 offer preliminary support for this approach. The study underscores the insights provided by theories and methods used in the fields of social movements research and peace and conflict studies.
\end{abstract}

The concept of terrorism is deeply emotive, power-laden, and contested. Thus, the frequent use of the term "terror" in public discourse provides an opportunity for academic research to resonate with the public. Yet, use of the term in research runs the danger of scholarly work legitimating the agendas of the powerful while overlooking oppression as an underlying source of insurgency. It also runs the risks of glossing over variations in the actors responsible for political violence against civilians as well as differences in the motivations of those responsible. These dangers and risks are evidenced by the ad-hoc analyses found in the $9 / 11$ literature. Much of this work is based on theories that have been discredited in the fields of social movement research and peace and conflict studies.

In contrast, this article calls for a contention-oriented approach to understanding political violence against civilians. We conceptualize four distinct types of political violence against civilians - selective, collective, categorical, and indiscriminate. Moreover, we argue that five facets of contention help to explain variations in the levels and forms of political violence against civilians: (1) the strategies of combatants; (2) the means of contention; (3) the locations of allies and opponents; (4) the collective identities of combatants; and (5) the dynamics of contention, including dynamics related to peace processes. Quantitative analyses of lethal political violence against civilians in Northern Ireland between 1966 and 2006 are used to illustrate the utility of the four-part typology, as well as to assess hypotheses regarding factors influencing each type of political violence against civilians. The analyses largely support our hypotheses, underscoring the promise of a contention-oriented approach.

\section{THEORETICAL APPROACHES BEYOND “TERROR"}

Scholars have developed a myriad of definitions of terror that variously emphasize the perpetrator of violence, the target of violence, and the intent of violence. We argue that because

\footnotetext{
- Our deepest appreciation goes to Jeff Goodwin for his inspiration, insights, and research assistants for this project. We also thank Denis O'Hearn, Lee Smithey, Robert White, and the anonymous reviewers for their helpful comments and suggestions. Earlier versions of this article were presented at the 2010 International Sociological Association conference in Göteborg, Sweden, and the 2011 American Sociological Association annual conference in Las Vegas.

${ }^{\dagger}$ Gregory M. Maney is Professor in the Department of Sociology at Hofstra University. Michael A. McCarthy is a graduate student in the Department of Sociology at New York University. Grace B. Yukich is Assistant Professor in the Department of Sociology at Quinnipiac University. Please direct all correspondence to socgmm@hofstra.edu.
} 
of a lack of definitional consensus, the pejorative character of the term, and challenges in its operationalization, researchers should use the term political violence instead of terrorism.

Several scholars limit perpetrators of terror to nonstate actors (see, for example, Sommier 2002; Bergesen and Lizardo 2004; Black 2004; LaFree and Ackerman 2009). Others, however, point out that states also commit acts of terror against civilians (Herman and O'Sullivan 1989; Gareau 2004; Goodwin 2006; Drake 2007; Froystad 2009). Defining political violence against civilians by nonstate actors as terrorism and political violence against civilians by state actors as something other than terrorism serves to delegitimate the actions of insurgents while legitimating the actions of state actors (San Juan, Jr. 2005; Butko 2006). It reinforces the taken-for-granted assumption that states rightfully have a monopoly over organized violence and use that monopoly for the good of their citizens. By using the term "terrorism" to only refer to the actions of nonstate actors, scholars are contributing to a dominant discourse that symbolically and strategically gives advantages to powerful actors (Woehrle, Coy, and Maney 2008). Subtly reinforcing the legitimacy of the state could be problematic when the state engages in human rights abuses against civilians who, in turn, rebel against the state.

Such distinctions also lead us in the wrong direction in understanding political violence against civilians. Some states commit extensive political violence against civilians to inspire fear and terror (Ball, Kobrak, and Spirer n.d.; Cohen and Corrado 2005; Gill 2007; Maher and Peterson 2008; Seri 2008; Froystad 2009). Using different labels to describe political violence against civilians by state actors versus nonstate actors precludes the exploration of possible similarities in the causes of the same behavior (Goodwin 2007). ${ }^{1}$

A greater degree of agreement exists regarding victims of terrorism, with most scholars limiting victims to civilians (see, for instance, Sommier 2002; Carr 2003; Bergesen and Lizardo 2004; Black 2004; Butko 2006; Goodwin 2006; Drake 2007; LaFree and Ackerman 2009). Yet the term civilian often remains undefined. As will be discussed in detail below, many actors outside the state are actively engaged in political contention, some of which is violent, either in opposition to or in defense of the state. Moreover, extreme acts of violence against combatants can also be intended to inspire fear.

This brings us to the use of intent in defining terrorism. Some scholars have defined terror as acts that either are intended to cause or actually do cause feelings of terror in one or more audiences (Walzer 2004; LaFree and Ackerman 2009). Jeff Goodwin (2006), however, points out that several definitions of terrorism do not refer to the intent or effect of inspiring terror or fear (Tilly 2004; Crenshaw 1981; Black 2004; Bergesen and Lizardo 2004). Assuming that political violence against civilians is always motivated by a desire to instill fear is questionable. Civilians may be terrorized by an act of political violence without this being the intent of the perpetrator. Given the necessity of sublimating these feelings to both create and cope with contexts of high levels of political violence, establishing what people actually feel about acts of political violence is difficult methodologically, not to mention problematic ethically in terms of the rights of human subjects.

Given these multiple limitations, we argue that sociologists should use the concept of political violence instead of terrorism. When compared to the concept of terrorism, the concept of political violence sensitizes analysts to variations in perpetrators, victims, intent, and consequences. At the same time, the term political emphasizes that the organized violence is committed in the pursuit of challenging or defending extant authority (Snow, Soule, and Kriesi 2004). As such, it avoids the tendency of pejorative terms like terrorism to portray those engaged in organized violence as unthinking and unreasoned and, therefore, incapable of being persuaded through education or negotiation.

\section{The Ghosts of Theories Past: Explaining Political Violence against Civilians}

While moving away from the concept of terrorism, it is nonetheless important to understand political violence against nonstate actors. Nonstate actors are more likely to be 
casualties of modern and postmodern warfare than are state actors (Azam 2006). Moreover, many "civilians" play important roles in political violence, either directly through participation in combat or indirectly through material and moral support for combatants (Gross 2009).

Given the prominence of Charles Tilly's work in the field, there has been a rather puzzling neglect of political violence by social movement researchers. Perhaps because of this neglect, much of the recent research on political violence against civilians by scholars in the fields of terrorism studies, security studies, and criminology draw from theories that have largely been discredited within the field of collective behavior and social movements. Some scholars have drawn on functionalism and early collective behavior theories to explain terrorism. Agnew (2010), for instance, has advanced a strain-based explanation. Gottschalk and Gottschalk (2004) attribute terrorism by nonstate actors in the Middle East to their authoritarian tendencies and pathological hatred. The authors explicitly reject rational motives for their actions. Explanations rooted in deprivation theory have also featured prominently (Senechal de la Roche 1996; Stern 2003; Black 2004).

Just as these theories were applied to innovative social movements threatening the power status quo in the 1950 s and 1960 s, they are now being applied to similarly innovative movements. That studies of "terrorism" in the immediate aftermath of $9 / 11$ have largely stigmatized insurgents and ignored political repression and structural violence as sources of armed conflict is hardly surprising. What is surprising is that social movement scholars have yet to apply contemporary theories and rigorous methods of research to challenge these studies. More recent social movement scholarship has much to offer in increasing our understanding of political violence against civilians. In this article we put forth a contentionoriented approach that emphasizes the goals, identities, strategies, and interactions among those involved, either directly or indirectly, in contention.

\section{A Contention-Oriented Approach}

We propose four categories of political violence that separate civilian victims based upon the nature and extent of their proximity to contention-selective, collateral, categorical, and indiscriminate. Goodwin (2006) distinguishes between selective and categorical political violence against civilians. Selective political violence against civilians involves political violence against specific nonstate actors targeted because of their perceived or actual behaviors. "Civilians" frequently participate directly in violent contention as members of police or military auxiliaries and reserves, militias, vigilante groups, and paramilitary organizations (Romero 2000; Branch 2005; Gross 2009). Some civilians become directly involved in less formal ways, such as participating in fights and riots that are politically related. Other civilians, while not directly participating in political violence, are seen as supporting it. Civilians also play a variety of other roles in political contention, including those of nonviolent activists, office holders, members of political parties, groups, or associations, informants, collaborators, provocateurs, fundraisers and financial supporters, service providers, outspoken lawyers, investigative journalists, and propagandists - to name a few. As such, it is often erroneous to assume that all civilians are "innocent" in the sense that they have not played a role in contention.

As political violence escalates, civilians are routinely pressured into becoming involved in contention. A failure to either support or to oppose participants can result in a civilian being targeted for violence. For example, civilians can be targeted simply for fraternizing with opposing combatants or complicit civilians. The act of "crossing over" is viewed as a betrayala violation of group commitment worthy of violent expiation (Maney 2005; Maney, Ibrahim, Higgins, and Herzog 2006). At other times, simply refusing to provide support requested by combatants can be grounds for being attacked. Ironically, the refusal to become involved in contention becomes a source of selective political violence. Moreover, persons who witness unlawful contentious acts and, therefore, threaten to bring about the incarceration or execution 
of combatants are likely to be targeted. In these ways, violent political contention colonizes the civilian population, decreasing the number of non-engaged persons.

Selective political violence includes not only targeting civilians because of their political roles, but also targeting civilians because of other roles and behaviors such as common criminal behaviors or personally offending one or more individuals participating in armed contention. Increased antisocial behaviors are a frequent by-product of the reduced ability of the state to enforce laws in insurgent strongholds. At the same time, paramilitary organizations and civil defense committees develop capacities to enforce rules through organized violence. Doing so often enhances the legitimacy of these actors in areas they relied on for providing members and support. In assuming the roles and functions of authorities, these actors in effect develop provisional governments. This is particularly important in signaling tangible progress toward revolutionary goals. In other instances, apolitical deviance is negatively sanctioned for political reasons. For instance, some paramilitary organizations fund their operations through drug dealing and/or bank robberies. Killing apolitical drug dealers and bank robbers effectively eliminates competition for resources used to fund paramilitary operations.

In addition to selectively targeting perceived criminals, individual combatants sometimes take advantage of their access to weaponry and relative protection from reprisal to act on grudges against acquaintances. For instance, studies of the Rwandan genocide reveal that many of the victims were murdered by those with whom they previously had disputes (Brubaker and Laitin 1998). Having theorized reasons why civilians are killed because of their perceived or actual behaviors, we now turn to explaining why civilians are targeted for no reason other than their social group affiliation.

In contrast to selective political violence, categorical political violence against civilians is political violence targeting nonstate actors because of their perceived or actual affiliation with a specific collectivity, regardless of whether or not they are involved in contention (Goodwin 2006). Collective bases for categorical political violence frequently include, but certainly are not limited to, ethnicity, religion, race, nationality, and social class. The colonizing logic of political contention also helps us to understand the tendency to view most, if not all, members of a collectivity as being complicit in contention. Moreover, creating strong discursive, relational, and physical boundaries with an opposing group facilitates the development of a strong movement identity and, in turn, high levels of active participation in the struggle (Taylor and Whittier 1992; Maney et al. 2006; White 2010). Ethnonationalist identities are particularly likely to be characterized by strong boundaries. All people are seen to be members of a nation by virtue of their shared cultural characteristics and/or demonstrations of national loyalty. Each member of the nation has rights that those who are not part of the nation do not have. These rights come with responsibilities to the nation; above all, the responsibility to take up arms in its defense. From the perspective of those holding such assumptions, it is impossible to conceive of a member of a nation who is not complicit in armed ethnonationalist struggle.

We propose two additional, distinct types of political violence against civilians: collateral political violence and indiscriminate political violence. Collateral political violence against civilians involves political violence against nonstate actors that results inadvertently from operations targeting other individuals believed to have played past or present roles in political contention. Those civilians who experience this type of violence are not the intended targets. ${ }^{2}$

There is still another type of political violence against civilians that has yet to be categorized: political violence against civilians who have no behavioral, physical, relational, or communal connection to contention. In other words, civilians who are targeted (as opposed to being collateral damage) are not perceived as playing either direct or indirect individual roles in contention and do not belong to a specific collectivity involved in the conflict. We refer to this phenomenon as indiscriminate political violence against civilians. Those without involvement or perceived complicity in political contention are the targets. ${ }^{3}$ 
We argue that behavioral, physical, and relational proximity of civilians to contention increases the likelihood that they will be the victims of political violence. Accordingly, we expect that indiscriminate political violence against civilians takes place the least among the four types (H1; see Appendix A for a list of all hypotheses). From a contention-oriented perspective, blind violence against civilians should be a relatively rare occurrence. A contentionoriented perspective also suggests that portrayals of civilian killings as mostly being categorical political violence motivated solely by sectarian hatreds ignore the likely prevalence of political violence based upon the behaviors of targeted civilians, as well as their physical proximity to contention. By virtue of their perceived influence on the outcome of contention, civilians participating in political contention are most likely to be targeted for violence by those seeking to eliminate their participation and (by example) similar participation by other civilians. To a lesser extent and as a byproduct of contention, we expect to see civilians targeted either because of their perceived common criminal behaviors or to carry out personal vendettas. In addition, civilians in close proximity to selective political violence are frequently caught in the crossfire, metaphorically and often literally. Participants in contention are often heavily guarded. It is also not uncommon for participants to surround themselves with civilians who serve as "human shields." After deterring or eliminating civilian opponents, we assume that strategic-minded actors have the greatest interest in deterring or eliminating those providing material and moral support to these opponents. Accordingly, we expect that over the course of a cycle of contention that selective and collateral political violence will constitute large percentages of civilian victims $(\mathrm{H} 2)$.

Having differentiated between four different types of political violence against civilians, we now theorize the causes of these phenomena. As part of a contention-oriented approach emphasizing the agency of participants (Jasper 2004), we argue that the levels and types of political violence against civilians depend in no small part upon the strategies of combatants.

\section{Strategies of Combatants}

Levels and types of political violence against civilians are likely to reflect plans of action for achieving the goals of the combatants within a given context. For example, both categorical and indiscriminate political violence can reflect a deliberate strategy of destabilization on the part of insurgents. In a colonial context, the financial costs to the state may provide sufficient incentive to territorially withdraw or separate. In the context of class-based conflict, the elimination of capital could be viewed as paving the way toward alternative forms of economic production. For insurgents not concerned with popular legitimacy, indiscriminate political violence can represent an attempt to eliminate mobilization on behalf of the state by civilians regardless of their social group affiliations. Accordingly, we hypothesize that major changes in the strategies of combatants are likely to lead to significant changes in the levels and types of political violence perpetrated against civilians (H3). The strategies of armed contention selected, in turn, depend upon factors familiar to social movement scholars, including the means of contention, assessments of allies and opponents, the collective identities of participants, and interactions among contenders (Maney, Kutz-Flamenbaum, Rohlinger, and Goodwin 2012).

\section{Means of Contention}

The means of contention influence the likelihood of political violence against civilians. Benini and Moulton (2004) find that civilians in Afghanistan were killed as the indirect effects of munitions used by allied forces as part of Operation Enduring Freedom. Horne (2002) and Sommier (2002) both argue that new military resources and technologies increase the capacity for destruction and, therefore, the likelihood of indiscriminate violence.

Some technologies for killing are less discriminating than others. In particular, explosives and plane crashes are more likely to result in higher numbers of civilian casualties compared 
to fists, rocks, knives, or bullets. As a result, relative access to different types of weaponry will greatly influence levels of political violence against civilians. In this regard, we expect that the increased availability of less discriminating weaponry increases all forms of political violence against civilians (H4). The availability of weaponry and other resources depends upon the presence and degree of support from those not directly participating in contention.

\section{Allies and Opponents}

Goodwin (2007: 2027) defines complicit civilians as noncombatants who benefit from, support, or have substantial capacity to influence opposing actors. He hypothesizes that categorical political violence against civilians is most likely to occur when opposing actors think that it is unlikely that they can draw support from complicit civilians. These actors are thought to be more likely to hold these perceptions in three contexts: (1) complicit civilians support extensive political violence; (2) complicit civilians are numerous and relatively unprotected; and (3) political alliances or cooperation between the political actor and the civilians in question are weak or absent due to strong linguistic, religious, and/or territorial segregation (Goodwin 2007: 2039-40). This leads us to expect that civilians in areas providing high levels of support for an armed actor are more likely to be victims of categorical political violence $(\mathrm{H} 5)$.

\section{Collective Identities of Combatants}

Levels of categorical violence against civilians can also be influenced by the collective identities of participants (Bhatt 2010). The perception of the potential of complicit civilians to be potential supporters of combatants is not only a product of social distance and history, but also very much a product of collective identity. The collective identities of some political actors may prevent them from engaging in high levels of political violence against complicit civilians, even when each of these three contextual factors discussed in the preceding subsection are present. State actors may seek to demobilize, if not convert, complicit civilians by arguing that they are citizens guaranteed equal rights and equal protection by the state. To engage in categorical political violence against these civilians would violate a rule of behavior and group commitment that could be central to the collective identity and/or discursive strategy of state building. Moreover, it would likely not only further de-legitimate the state but also intensify levels of both participation in and support for insurgents.

Nonstate political actors may eschew categorical political violence for similar reasons. They may construct their collective identities as being inclusive of all nonstate actors even when civilians draw strong identity boundaries between themselves and the insurgents. To engage in categorical terrorism would violate a fundamental rule of behavior and group commitment (that is, it would be transgressive from the perspective of the insurgents). Accordingly, we expect that combatants with more inclusive collective identities will be less likely to engage in categorical political violence than combatants with more exclusive collective identities (H6). Nonetheless, strong identity commitments may not be sufficient to constrain political violence against civilians in response to provocation.

\section{Dynamics of Contention}

Interactions among combatants often contribute to changes in both the levels and types of political violence against civilians. An escalation in political violence by one actor is likely to be reciprocated by opponents in an effort to raise the costs of such behaviors (Herman and O'Sullivan 1989; Maney 2005; LaFree, Dugan, and Korte 2009; Ukiwo 2009). In the process, a tit-for-tat dynamic ensues, often culminating in an outward spiral of political violence. Specific types of political violence against civilians are likely to be reciprocated, particularly

when they have the capacities and are not constrained by identity-based commitments. At a 
certain point, as civilian casualties rapidly mount, one or more of the actors may deliberately reduce their violence against civilians in the hopes that others will follow suit. Because of this tendency toward tactical convergence, we expect that major, sustained increases or decreases in political violence against civilians by an armed actor are likely to be reciprocated by opponents ( $\mathrm{H} 7)$.

Peace processes can constitute efforts to de-escalate armed conflict. Those participating in peace processes mostly reduce their levels of political violence against both combatants and civilians. However, there are occasions where participants engage in efforts to increase their bargaining leverage at the negotiating table (Kriesberg 1998; Darby and MacGinty 2003). Moreover, for those armed actors not participating - either by involuntary exclusion or voluntary refusal-peace processes are also likely to increase their categorical political violence as they seek to undermine public support by heightening polarization, mistrust, and uncertainty (Stedman 1997; Darby 2001; Newman and Richmond 2006). Accordingly, we expect categorical political violence to increase during peace processes largely exclusive of paramilitary organizations and to decrease during peace processes mostly inclusive of paramilitary organizations (H8).

\section{METHODOLOGY}

Quantitative methodologies lend themselves to establishing variations in types of political violence against civilians. Unfortunately, most studies have either examined political violence without distinguishing between civilian and combatant status or have failed to differentiate between different types of political violence. This absence can be largely attributed to two factors. First, detailed information on the circumstances and motives surrounding civilian killings is often difficult to obtain. Second, such information tends to be deeply disputed given its implications for the relative legitimacy of the actors involved in contention.

This article examines political violence against civilians in Northern Ireland between 1966 and 2006 (see Appendix B for a glossary of case-related terminology). Created through an act of parliament, a peace treaty, and force of arms in the early 1920 s, Northern Ireland is a distinct political entity, comprising six of the thirty-two counties of the island of Ireland. It is constitutionally linked with Great Britain as part of the United Kingdom. The other twenty-six counties of Ireland are known as the Republic of Ireland, which was declared a sovereign, independent republic in the constitution of 1937 and reaffirmed by an act of parliament in 1949. In 1966, the fiftieth anniversary of the Easter Rising, Loyalists feared an upsurge in Republican attacks and undertook a series of random killings of Nationalists, led by the newly formed paramilitary organization, the Ulster Volunteer Force. In 1968, mass civil rights mobilization placed pressure upon the British state to force the Unionist-controlled Northern Ireland state to redress the Nationalist population's grievances. Widespread rioting and the subsequent introduction of British soldiers on the streets of Northern Ireland in August, 1969, marked the beginning of a rapid escalation in political violence. The year 1972 brought the highest level of politically related fatalities that Northern Ireland had ever experienced. Levels of political violence declined markedly after 1976 with a number of subsequent spikes, particularly during the hunger strikes of the early 1980s and the beginning of the peace process that led to the signing and ratification of the Belfast "Good Friday" Agreement in 1998. While the killing of civilians by Northern Ireland security forces largely ended in the mid-1990s, both Loyalist and dissident Republican paramilitaries continue these practices.

We believe that the Northern Ireland is an ideal case for advancing our understanding of political violence against civilians. It is arguable that the "Troubles" in Northern Ireland have received more scholarly and media attention than any other ethnonationalist conflict. As a result, detailed documentation exists on most civilian killings, allowing for their classification into one of the four categories of political violence discussed above. The existence of multiple 
sources of data on civilian killings allows for both greater detail and greater confidence regarding classification. For this article, we used the following data sources: Sutton 2001; Conflict Archive on the Internet nd; McKeown 2009; McKittrick 2004; findings by the Independent Monitoring Commission 2004-2006; reports of the Police Service of Northern Ireland Historical Enquiries Team 2005 to present; rulings by the European Court of Human Rights; and the Saville Inquiry Report released in 2010. Moreover, in contrast to other cases of armed conflict, month and year-level time-series data exists for several measures that can help us to assess contextual factors influencing the prevalence of different forms of terrorism against civilians. Findings on the basis of one case are preliminary and exploratory. However, given the absence of this type of research, coupled with the influence of Northern Ireland upon other ethnonationalist conflicts, the findings will provide an important first step toward the rigorous analysis of political violence against civilians.

\section{Disaggregating Political Violence against Civilians}

Each instance of a politically motivated killing of a civilian was classified into one of five motivational categories: (1) selective political violence; (2) collateral political violence; (3) categorical political violence; (4) indiscriminate political violence; or (5) uncertain. A death was coded as selective political violence if the preponderance of evidence suggests that the civilian was killed because of either her or his perceived or actual individual identity, role, or behavior (for example, combatant; excombatant; political activist; common criminal). A death was coded as collateral political violence if the preponderance of evidence suggests that the person killed was not the intended target. A death was coded as categorical political violence if the perpetrator had no apparent reason to kill the targeted civilian other than her or his ethnonationalist affiliation. While some Protestants favor reunification and some Catholics favor Northern Ireland remaining in the United Kingdom, they constitute very small minorities. Accordingly, Protestants are used as a proxy measure for Unionists and Catholics for Nationalists. A death was coded as indiscriminate political violence if the civilian killed was: (1) of the same ethnonationalist affiliation; (2) not killed because of their individual identity, role, or behavior; and (3) not the victim of collateral political violence. Seventy-seven deaths were placed in an "uncertain" category and excluded from the analysis due to: (1) insufficient information; (2) the absence of a majority or definitive opinion among the sources regarding the perpetrator and motivation for the killing; or (3) multiple motivations for the killing, thus preventing the exclusive assignment of the case to one of the four categories.

Killings were also classified in one of four general perpetrating actor categories: (1) Northern Ireland security forces; (2) Loyalist-affiliated individuals or organizations; (3) a combination of Northern Ireland security forces and Loyalist-affiliated individuals or organizations; and (4) Republican-affiliated individuals or organizations. It is possible that some of the cases have been erroneously classified. Intersource validation coupled with the large number of cases, however, provides a high degree of confidence in the validity of the aggregated findings.

We used Cohen's kappa as a measure to assess the rate of inter-coder agreement among the three coders. A sample of 300 cases coded by two of the coders in all possible dyadic combinations yielded a combined kappa score of 0.63 . This score is generally considered to indicate a substantial rate of agreement among the coders (see Landis and Koch 1977; Sim and Wright 2005). The data enable us to assess the relative engagement in different types of political violence against civilians by different political actors over the course of the Troubles.

\section{Contextualizing Political Violence against Civilians}

We examine factors possibly influencing levels and types of political violence against civilians. To do this, we ran time-series and logistic regressions of the number of killings 
within the category on selected independent variables (see Appendix $\mathrm{C}$ for a discussion of regression diagnostics and remedies). All independent variables in time-series regressions were lagged. Independent variables were selected on the basis of their operationalization of concepts used in hypotheses along with the availability of continuous time-series data.

\section{Strategy of Combatants}

To assess whether shifts in paramilitary strategy affect levels and types of political violence against civilians, we created dummy variables for three distinct strategic phases of the armed Republican Struggle during the Troubles: an all out offensive strategy by the Provisional Irish Republican Army (IRA) after the split of the republican movement; the adoption of the long war strategy after a ceasefire and negotiations with the British government in 1975 and 1976; and the TUAS Strategy articulated in an internal Republican document believed to have been circulated in 1994 before being leaked in 1995 (see English 2002; Moloney 2002; White 2006). TUAS is widely thought to stand for either Tactical Use of Armed Struggle or Totally Unarmed Strategy. We expect categorical violence by Republicans to be highest during the all out offensive and lowest during the TUAS phase.

\section{Means of Contention}

We hypothesized that the availability of different types of weaponry would affect levels of political violence against civilians. Accordingly, in month-level time series regression analyses, we include measures of the number of shooting incidents, as well as the number of explosive devices used. The data come from the Annual Abstract of Statistics, Report of the Chief Constable, and the Police Service Northern Ireland's Statistic's branches website. Per Robert White (1993), month level figures are estimated by apportioning changes between the year level data over a 12-month period.

\section{Allies and Opponents}

We created dummy variables for whether or not the location where a civilian was killed was a loyalist paramilitary stronghold or a republican paramilitary stronghold. We compiled a list of Republican strongholds from the geographically based brigade and battalion structure of the Provisional IRA prior to its reorganization in 1977, and a list of the home residences of current Republican prisoners supplied by the Sinn Féin POW Department. Given declining participation upon the adoption of the Long War strategy, locations in the Republic of Ireland coded as Republican strongholds prior to December 3, 1977 (the date of a change in the IRA's Chief of Staff) were not coded as Republican strongholds after December 2, 1977. Similarly, we compiled a list of Loyalist strongholds based upon the brigade areas of the Ulster Defence Association and the Ulster Volunteer Force.

\section{Collective Identities of Combatants}

Drawing upon the same sources used to categorize types of political violence against civilians, we created variables limiting political violence to one of the following perpetrators: Loyalists, Republicans, or security forces. Because Republican identity is more inclusive of Protestants than Loyalist identity is inclusive of Catholics, we expect Republicans to engage in less categorical political violence than Loyalists.

\section{Dynamics of Contention}

To get at the possibility of the emergence of a tit-for-tat dynamic, the number of killings by opposing political actors was included in certain time-series regression analyses. The dependent variable was also lagged to provide a measure of a sustained campaign. To assess 
whether or not opponents would reciprocate de-escalation, we created a binary variable for whether or not a ceasefire by the Provisional IRA was in effect. The Akaike Information Criterion was used to determine the appropriate lag for each model.

Above we argued that peace processes are likely to have different effects upon violence against civilians depending upon whether or not paramilitary organizations are included in the negotiations. Accordingly, we created two binary variables: one for peace processes that were exclusive of Loyalist and Republican paramilitary organizations (such as the Sunningdale negotiations and Agreement; the Constitutional Convention; the first Northern Ireland Assembly; and the Anglo-Irish Agreement), and the other for the negotiations, signing, and ratification through referenda of the Belfast Good Friday Agreement (BGFA). The BGFA process was the first and only peace process during the Troubles to include representatives of Loyalist and Republican paramilitary organizations.

\section{Control Measures}

Taking the lead from White (1993), unadjusted employment rates were included as a measure of deprivation in month-level time series regression analyses. The data come from three sources: the Digest of Statistics, the Annual Abstract of Statistics, and a report by the Northern Ireland Statistical Research Agency. Discrepancies existed between figures for the same years provided by different sources. Accordingly, figures were weighted using ratios to standardize the data.

Again taking the lead from White (1993), as a general measure of repressive capacity we used Annual Abstract of Statistics, Report of the Chief Constable, and the Police Service Northern Ireland's Statistic's branches website to compile the number of security forces in Northern Ireland in a given year. Given the findings by several quantitative studies of a curvilinear relationship between repression and insurgency, we also include a squared term in the regression model.

\section{RESULTS}

Table 1 disaggregates civilian deaths by four types of political violence against civilians by the agent responsible. The findings support our first two hypotheses (again, see Appendix A for a list of hypotheses). Of the four categories of political violence against civilians, indiscriminate killings account for the lowest percentage of fatalities ( 3.0 percent). Even with the Provisional IRA's targeting of businesses as part of its economic destabilization efforts in the early 1970 s, only 4.3 percent of civilians who lost their lives to Republican violence were killed indiscriminately. Whether due to the desire not to alienate constituencies, a deep identification with their co-nationals, or a combination of material and symbolic factors, indiscriminate political violence was not a prominent part of the repertoire of armed contention during the Troubles.

The Troubles were often portrayed as a sectarian conflict where civilians were mostly killed for no reason other than their ethnonationalist affiliation. If this were the case, then categorical violence should account for the majority of civilian deaths. Table 1, however, reveals that selective and collateral political violence together accounted for 61 percent of civilian deaths. Almost half the time (48 percent) civilians were killed because of their perceived or actual behaviors. We coded 18 separate categories of behaviors that motivated killings. Over half ( 56.7 percent) of such killings were the result of either the perception or the reality that the victim was active in a paramilitary organization. Civilians were also frequently killed because they were believed to be or actually were involved in antisocial behavior ( 6.8 percent of selective violence), informing (5.8 percent of selective violence), political activism ( 5.6 percent of selective violence), or providing services to an opponent ( 4.5 percent). Excombatants were also often targeted (5.6 percent of selective violence). With one 
Table 1. Lethal Political Violence against Civilians by Perpetrator and Type

\begin{tabular}{|c|c|c|c|c|c|}
\hline & Select & Collateral & Categorical & Indiscriminate & Total \\
\hline & $\begin{array}{c}N \\
\text { (row \%) }\end{array}$ & $\begin{array}{c}N \\
\text { (row \%) }\end{array}$ & $\begin{array}{c}N \\
\text { (row \%) }\end{array}$ & $\begin{array}{c}N \\
(\text { row \%) }\end{array}$ & $\begin{array}{c}N \\
\text { (col. \%) }\end{array}$ \\
\hline \multirow[t]{2}{*}{ NI Security Forces } & 268 & 44 & 45 & 0 & 357 \\
\hline & $(75.1 \%)$ & $(12.3 \%)$ & $(12.6 \%)$ & $(0.0 \%)$ & $(14.1 \%)$ \\
\hline \multirow[t]{2}{*}{ Loyalists } & 306 & 61 & 556 & 27 & 950 \\
\hline & $(32.2 \%)$ & $(6.4 \%)$ & $(58.5 \%)$ & $(2.8 \%)$ & $(37.5 \%)$ \\
\hline \multirow[t]{2}{*}{ NISF and Loyalist } & 33 & 5 & 90 & 2 & 130 \\
\hline & $(25.4 \%)$ & $(3.8 \%)$ & $(69.2 \%)$ & $(1.5 \%)$ & $(5.1 \%)$ \\
\hline \multirow[t]{2}{*}{ Republicans } & 607 & 218 & 222 & 47 & 1,094 \\
\hline & $(55.5 \%)$ & $(19.9 \%)$ & $(20.3 \%)$ & $(4.3 \%)$ & $(43.2 \%)$ \\
\hline \multirow[t]{2}{*}{ Total } & 1,214 & 328 & 913 & 76 & 2,531 \\
\hline & $(48.0 \%)$ & $(13.0 \%)$ & $(36.1 \%)$ & $(3.0 \%)$ & $(100.0 \%)$ \\
\hline
\end{tabular}

Notes: Includes the deaths of civilian combatants.

exception, these behaviors were directly related to contention. Individual civilians were frequently targeted for their perceived or actual involvement in antisocial behaviors. In a context where actors are armed to the teeth and paramilitary organizations assume responsibility for norm enforcement in areas that security forces are unwelcomed, civilians are more likely to pay the ultimate price for disturbing the apolitical social order in their communities.

An additional $13 \%$ of civilians killed between 1966 and 2006 died because they were in the immediate proximity of armed contention. Of the 328 instances of lethal collateral political violence identified, most civilians $(82 \%)$ were killed during operations either targeting combatants $(66.2 \%)$ or noncombatants $(15.8 \%)$. The remainder were killed either because guns or explosives accidentally went off during robberies or at security force checkpoints.

The results in table 1 provide important correctives to the most popular misconceptions of political violence against civilians during the Troubles. The majority of civilian deaths were closely tied to contention. Focusing primarily upon categorical political violence ignores the prevalence of political violence based upon the perceived or actual behaviors of civilians, as well as their physical proximity to contention. This is not to say, however, that categorical political violence did not frequently take place. On the contrary, over one-third $(36.1 \%)$ of deaths involved civilians who were targeted for no apparent reason other than their ethnonationalist affiliation. Findings presented below demonstrate how contention-related factors provide strong indicators of categorical political violence against civilians.

Table 1 reveals not only multiple types of political violence against civilians, but also violent propensities according to political actors. Republicans engaged in higher levels of both selective and collateral political violence than either Loyalists or Northern Ireland Security Forces. Moreover, Loyalists engaged in more categorical political violence than either Republicans or Northern Ireland Security Forces. When including killings involving collusion with security forces, nearly three-fifths ( 59.2 percent) of killings by Loyalists randomly targeted Catholic civilians. In contrast, less than one quarter (20.3 percent) of Republican killings of civilians randomly targeted Protestants. These variations across political actors can be explained by contention-related factors, to which we now turn our attention.

\section{Strategy and Lethal Political Violence against Civilians}

We hypothesized that changes in the strategies of combatants would produce changes in the levels and forms of political violence against civilians not directly participating in armed 
Figure 1. Republican Killings of Civilians by Type

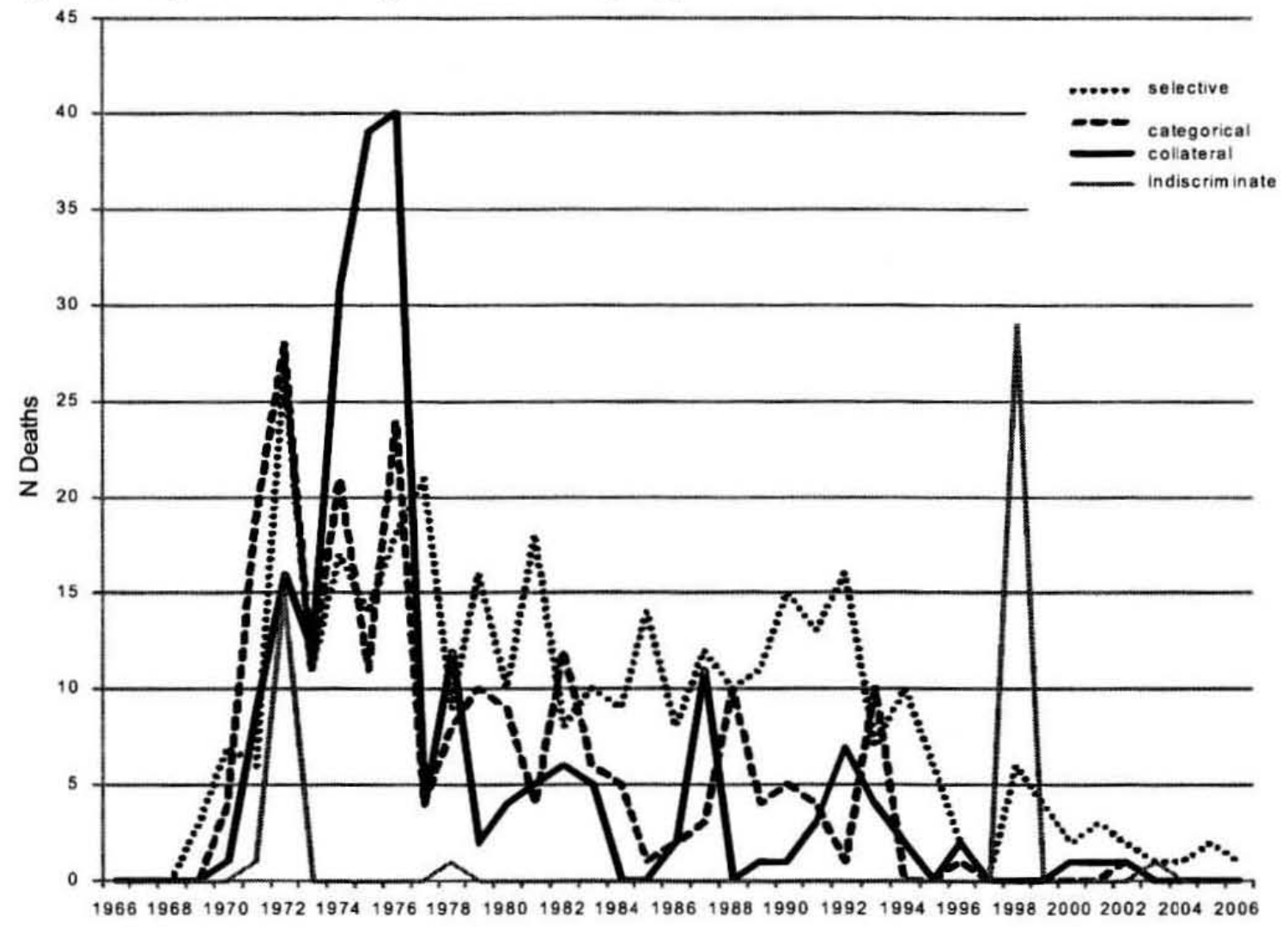

conflict (see H3). Figure 1 presents forms of lethal political violence against noncombatant civilians by Republicans over a 40 -year period. The figure shows considerable variation in both the levels and predominant forms of Republican political violence against civilians over the course of the Troubles. With the exception of indiscriminate political violence, which appears only sporadically, there is an overall downward trend for each form of political violence against civilians. This trend closely mirrors the Provisional IRA's strategic shift from an all out offensive (1970-1977) to a "long war" strategy of protracted, low-intensity conflict (1978-1992), and finally, to a move away from armed struggle (1992-present).

Changes in the type of political violence against civilians perpetrated by Republicans were tightly coupled with shifts in the Provisional IRA's strategy. In 1975, negotiations with the British government failed to produce tangible progress towards reunification. A near yearlong ceasefire also contributed to the permanent demobilization of a large number of volunteers. At the same time, the British government managed to create several informants within the ranks of the organization. Collectively, these developments prompted a change in strategy in 1977. Abandoning conventional brigades, the IRA was reorganized into cell structures to reduce the likelihood of infiltration. Rather than trying to score a decisive, immediate victory by making Northern Ireland ungovernable and destabilizing the economy, the goal was to win through a long war of attrition. As a result, operations became more selective and focused upon combatant targets. Lethal categorical political violence went from a high of forty civilians in 1976 to four civilians in 1977. Similarly, lethal collateral political violence decreased from 24 civilians in 1976 to 4 civilians in 1977. At the same time, lethal selective political violence against civilian noncombatants increased from 18 in 1976 to 21 civilians in 1977.

The year 1993 marked the start of an decline in both selective and categorical killings by Republicans. The timing reflects the decision by the Army Council to signal their willingness to become involved in peace negotiations. During a speech on December 16, 1992, British Secretary of State for Northern Ireland, Patrick Mayhew, indicated the possibility of including 
Sinn Féin (the political wing of the IRA) in future talks on the constitutional status of Northern Ireland. A little over a week later the IRA declared a three-day ceasefire, marking the first in a series of ceasefires that eventually culminated in the complete decommissioning of IRA weaponry by September of 2005.

The spike in indiscriminate political violence in 1998 is accounted for by one bombing by Real IRA - an organization opposed to the Belfast Good Friday Peace Agreement. By all accounts, this effort to undermine the Agreement had the opposite effect, reminding former combatants and the general public of the costs of an alternative to a negotiated compromise. Overall, the results underscore the importance of the strategies of combatants to understanding levels and forms of political violence against civilians. We now look at several factors influencing the strategies of combatants, starting with the means of contention.

\section{Means of Contention}

Table 2 presents the findings from month-level time series regressions of different types of lethal political violence against civilians on select independent variables. In addition to independent variables included in most time-series analyses of political violence in Northern Ireland (White 1993; Sullivan 1998; Maney 2007), we include measures for levels of usage of both discriminate weaponry (firearms) and indiscriminate weaponry (explosive devices).

Table 2. Unstandardized Coefficients for Time Series Regressions of Lethal Violence against Civilians on Selected Independent Variables: February 1966 to December 2006

\begin{tabular}{lcccc}
\hline & $\begin{array}{c}\text { Selective } \\
\text { Killings }\end{array}$ & $\begin{array}{c}\text { Collateral } \\
\text { Killings }\end{array}$ & $\begin{array}{c}\text { Categorical } \\
\text { Killings }\end{array}$ & $\begin{array}{c}\text { Indiscriminate } \\
\text { Killings }\end{array}$ \\
\hline Dependent Variable (lagged) & .036 & -.298 & .042 & -.220 \\
Repressive Capacity & $(1.72)$ & $(-4.59)^{* * *}$ & $(1.68)$ & $(-7.54)^{* * *}$ \\
(Repressive Capacity) ${ }^{2} \times 10^{-6}$ & -.000 & -.001 & -.000 & -.000 \\
& $(-0.73)$ & $(-2.90)^{* *}$ & $(-3.37)^{* *}$ & $(-0.51)$ \\
Truce & .000 & .001 & .002 & .000 \\
& $(0.76)$ & $(2.66)^{* *}$ & $(3.74)^{* * *}$ & $(0.34)$ \\
Percent Unemployed & -.059 & 1.155 & .463 & .690 \\
& $(-0.31)$ & $(2.05)^{*}$ & $(1.74)$ & $(1.23)$ \\
Discriminate Weaponry & .058 & .101 & .046 & .035 \\
& $(4.04)^{* * *}$ & $(2.23)^{*}$ & $(1.73)$ & $(0.82)$ \\
Indiscriminate Weaponry & -.000 & -.000 & .000 & .000 \\
Constant & $(-1.07)$ & $(0.32)$ & $(0.46)$ & $(0.80)$ \\
& .001 & .004 & .002 & .001 \\
$R^{2}$ & $(3.93)^{* * * * * *}$ & $(3.89)^{* * *}$ & $(5.04)^{* * *}$ & $(1.15)$ \\
B-G LM Stat. (D-W Stat.) & .395 & 7.281 & 5.018 & .262 \\
Number of cases & $(0.19)$ & $(2.94)^{* *}$ & $(2.22)^{*}$ & $(0.30)$ \\
Estimation technique & .26 & .25 & .29 & .07 \\
& 1.13 & $(1.97)$ & 0.01 & $(1.99)$ \\
\hline
\end{tabular}

Notes: $\mathrm{p}<.05, " \mathrm{p}<.01{ }^{\prime \prime} \mathrm{p}<.001$ (one-tailed). Excludes deaths of combatant civilians. Independent variables are lagged one month. The Breusch-Godfrey test (B-G LM Stat.) is used to detect serial correlation in Ordinary Least Squares regressions. The Durbin-Watson test (D-W Stat.) is used to detect serial correlation in P-W AR(1) regressions. Negative binomial regressions are used in cases where no serial correlation was detected. Instances of serial correlation are remedied using the Prais-Winsten transformed regression estimator [P-W AR(1)]. Numbers in parentheses are z-scores for negative binomial regressions and t-scores for Prais-Winsten regressions. 
The analysis supports our expectation that the increased availability of less discriminating weaponry increases political violence against civilians (see $\mathrm{H} 4$ ). The number of explosive devices used had a strong, positive relationship to levels of selective killings, collateral killings, and categorical killings. ${ }^{4}$ The findings underscore the way contention type impacts levels of political violence against civilians.

\section{Allies and Opponents}

Are civilians located in areas characterized by high levels of direct participation and indirect support for paramilitary organizations more likely to be victims of categorical political violence? The inclusion of location measures required switching from time series data to data where individual civilian deaths constitute the unit of analysis. We ran logit models for lethal categorical political violence by type of actor on select independent variables. Table 3 presents the findings.

The location of civilians in paramilitary strongholds was significantly related to lethal categorical political violence by Republicans, Loyalists, and Security Forces. Consistent with Hypothesis 5 and the idea that combatants attempt to raise the costs to civilians complicit with opponents, Loyalists and Security Forces frequently targeted civilians in areas characterized by high levels of participation in and support for Republican paramilitary organizations. The flipside of punishing civilians complicit with opponents is protecting civilians in allied areas. Northern Ireland security forces were significantly less likely to kill civilians in Loyalist paramilitary strongholds.

Table 3. Unstandardized Coefficients for Logistic Regressions of Lethal Categorical Political Violence against Civilians by Specific Perpetrators on Selected Independent Variables

\begin{tabular}{|c|c|c|c|}
\hline & $\begin{array}{l}\text { LCPVC } \\
\text { by Republicans }\end{array}$ & $\begin{array}{c}\text { LCPVC } \\
\text { by Loyalists }\end{array}$ & $\begin{array}{c}\text { LCPVC } \\
\text { by Security Forces }\end{array}$ \\
\hline PIRA All Out Offensive & $\begin{array}{c}.555 \\
(2.59)^{\circ}\end{array}$ & $\begin{array}{c}.456 \\
(4.04)\end{array}$ & $\begin{array}{l}1.995 \\
(6.25)\end{array}$ \\
\hline Truce & $\begin{array}{c}.712 \\
(4.09) \cdots\end{array}$ & $\begin{array}{c}-.081 \\
(-0.60)\end{array}$ & $\begin{array}{l}.235 \\
(0.99)\end{array}$ \\
\hline Exclusive Peace Processes & $\begin{array}{l}.059 \\
(0.30)\end{array}$ & $\begin{array}{c}.424 \\
(3.82)\end{array}$ & $\begin{array}{l}.295 \\
(1.41)\end{array}$ \\
\hline Belfast GF Agreement & $-^{a}$ & $\begin{array}{l}1.359 \\
(3.50)^{\cdots *}\end{array}$ & $-^{a}$ \\
\hline Loyalist Stronghold & $\begin{array}{l}.183 \\
(1.01)\end{array}$ & $\begin{array}{l}.580 \\
(4.63)\end{array}$ & $\begin{array}{l}-1.044 \\
(-2.84)\end{array}$ \\
\hline Republican Stronghold & $\begin{array}{c}-.913 \\
(-4.51)\end{array}$ & $\begin{array}{l}.241 \\
(2.21)^{\circ}\end{array}$ & $\begin{array}{l}1.001 \\
(4.97) \cdots\end{array}$ \\
\hline Constant & $\begin{array}{c}-2.533 \\
(-14.83)\end{array}$ & $\begin{array}{c}-1.339 \\
(-13.55)\end{array}$ & $\begin{array}{c}-4.605 \\
(-14.71)\end{array}$ \\
\hline Pseudo $R^{2}$ & .05 & .04 & .15 \\
\hline Number of cases & 1,861 & 1,891 & 1,861 \\
\hline Estimation technique & Logit Robust SE & Logit Robust SE & Logit Robust SE \\
\hline
\end{tabular}


Catholic civilians' presence in Loyalist paramilitary strongholds also increased their likelihood of being killed. The finding may reflect attempts by Loyalist paramilitaries to reduce negative sanctioning for lethal categorical violence. Killing complicit civilians in one's own area decreased the likelihood of encountering armed Republican patrols protecting their strongholds as well as the likelihood of civilians coming forward as witnesses. The killings might also have been part of efforts to secure territorial control by forcibly excluding Catholics from Loyalist neighborhoods. ${ }^{5}$

Inconsistent with our hypothesis, lethal categorical political violence by Republicans was not significantly related to a civilian's location in a Loyalist paramilitary stronghold. Moreover, unlike Loyalists, Republicans were significantly less likely to kill Protestant civilians located in Republican strongholds. We attribute these anomalous findings to collective identity differences among the combatants.

\section{Collective Identities of Combatants}

We expected combatants drawing inclusive identity boundaries to be less likely to engage in categorical political violence against complicit civilians than combatants drawing exclusive identity boundaries (see H6). Consistent with this expectation, categorical political violence constituted 20.3 percent of lethal violence against civilians by Republicans compared to 59.2 percent of lethal violence against civilians by Loyalists. ${ }^{6}$ Loyalists generally view the mainly Catholic Nationalist population as complicit in Republican paramilitary operations and unlikely to ever be convinced to support Northern Ireland being part of the United Kingdom. In contrast, to engage in higher levels of categorical violence would severely undermine the credibility of claims by Republicans that they are engaged in a nonsectarian, anticolonial liberation struggle. The results suggest that collective identities play critical roles in political violence against civilians.

\section{Dynamics of Contention}

To ascertain whether or not combatants influenced one another's behaviors, we ran time series regressions that include lagged measures of lethal political violence against civilians committed by other actors. We used the Akaike Information Criterion to select the appropriate time lag for each model. Table 4 presents the results.

The findings are mostly consistent with our expectation that combatants reciprocate major escalating and de-escalating actions by opponents (see H7). Lethal violence against noncombatant civilians by Republicans was positively related to lethal violence against noncombatant civilians by Loyalists (and vice versa). Loyalists and Security Forces escalated political violence against noncombatant civilians during, and likely in response to, the PIRA's all out offensive strategy of the early to mid-1970s. Conversely, Loyalists responded to PIRA ceasefires by significantly decreasing their killings of noncombatant civilians. The results suggest to us that both Loyalists and Republicans used noncombatant civilian killings as ways to raise the costs of further civilian killings by their opponents. A series of tit-for-tat responses often resulted in an outward spiral of political violence against civilians.

It is important to note, however, that security forces did not immediately and significantly alter their levels of political violence against noncombatant civilians in response to civilian killings by either Republicans or Loyalists. In a month-level regression of all political deaths in Northern Ireland, Maney (2007: 83) found that increases in killings by Republicans were positively related to subsequent killings by Security Forces. The combination of these results and the findings in table 4 raises the possibility that political violence against civilians by Security Forces was more likely to be affected by Republican killings of security personnel than Republican killings of civilians. Such a relationship would not be surprising given the presence of large numbers of British soldiers who were not from either Loyalist or Republican 
Table 4. Unstandardized Coefficients for Time-Series Regressions of Lethal Political Violence against Civilians by Specific Perpetrator: January 2, 1966 to December 31, 2006

\begin{tabular}{lccc}
\hline & $\begin{array}{c}\text { LPVC } \\
\text { by Republicans }\end{array}$ & $\begin{array}{c}\text { LPVC } \\
\text { by Loyalists }\end{array}$ & $\begin{array}{c}\text { LPVC } \\
\text { by Security Forces }\end{array}$ \\
\hline PIRA All Out Offensive & 1.153 & 1.522 & .031 \\
Truce & $(9.17)^{* * *}$ & $(14.89)^{* * *}$ & $(3.63)^{* *}$ \\
Exclusive Peace Processes & -.471 & -.331 & -.011 \\
& $(-1.84)$ & $(-3.05)^{* *}$ & $(-5.00)^{* * *}$ \\
Belfast Good Friday Agreement & .433 & .330 & -.011 \\
& $(3.11)^{* *}$ & $(3.09)^{* *}$ & $(-2.30)^{*}$ \\
LPVNC by Republicans & -1.323 & .157 & -.005 \\
& $(-3.02)^{* *}$ & $(0.70)$ & $(-2.50)^{*}$ \\
LPVNC by Loyalists & -.058 & .209 & -.001 \\
& $(-0.67)^{*}$ & $(2.59)^{*}$ & $(-0.41)$ \\
LPVNC by Security Forces & .251 & .792 & .003 \\
Constant & $(2.95)^{* *}$ & $(4.80)^{* * *}$ & $(0.23)$ \\
Pseudo $R^{2}$ & .260 & .177 & .109 \\
B-G LM Stat. (D-W Stat.) & $(1.10)$ & $(0.35)$ & $(1.34)$ \\
Number of lags on IVARs ${ }^{a}$ & -3.261 & -3.482 & -7.196 \\
Number of cases & $(-32.85)^{* * * * *}$ & $(-48.73)^{* * *}$ & $(-21.85)^{* *}$ \\
Estimation technique & .04 & .08 & .02 \\
& 0.44 & 0.28 & $(183)$ \\
\hline
\end{tabular}

Notes: $\mathrm{p}<.05, " \mathrm{p}<.01 \cdots " \mathrm{p}<.001$ (one-tailed). Excludes deaths of combatant civilians. The Breusch-Godfrey test (B-G LM Stat.) is used to detect serial correlation in Ordinary Least Squares regressions. The Durbin-Watson test (DW Stat.) is used to detect serial correlation in P-W AR(1) regressions. Numbers in parentheses are z-scores. Cases of collusion between Loyalists and Security Forces are excluded to avoid multicollinearity problems.

${ }^{a}$ Independent variables are lagged. Number of lags determined using the Akaike Information Criterion.

areas. A lack of identification with either ethnonationalist group could explain a lack of a concerted response. Unfortunately, our data does not include a measure for deaths of Security Force members. Further research is needed on this subject.

Peace processes had important effects upon levels of lethal political violence against civilians. Consistent with Hypothesis 8 , killings of noncombatant civilians by both Loyalists and Republicans increased significantly during peace processes that excluded them. Conversely, Republican violence against civilians decreased significantly during the one peace process that included them-the process culminating in the Belfast Good Friday Agreement (BGFA). Reflecting the lower degree of Unionist support for the negotiations and their outcome, there was no significant relationship between civilian killings by Loyalists and the BGFA. Nonetheless, the finding that Loyalist killings of civilians was not positively related to a peace process that included them is a noteworthy departure from responses to past peace processes that excluded them. Reflective of the British government's efforts to maximize public support for peace processes, civilian killings by security forces significantly decreased regardless of whether or not peace processes were inclusive of paramilitary groups. Overall, the findings suggest that negotiation is more effective than repression in reducing political violence against civilians by paramilitary organizations. 


\section{CONCLUSIONS}

Unfortunately, recent academic studies are characterized by a lack of consensus on how to define terrorism. Ironically, they also give prevalence to monocausal explanations that are strangely reminiscent of early, now-discarded social movement theories. Drawing on contemporary theories and methods from social movement research and from peace and conflict studies, we have suggested a contention-oriented approach that broadens our understanding of political violence against civilians. Both fields sensitize us to the relevance of discourse to power and resistance. Accordingly, we jettison the concept of terror in favor of the concept of political violence of civilians. This alternative terminology not only facilitates a greater degree of analytic neutrality, it also assists in the recognition of multiple types of perpetrators and different motivations for why civilians are killed.

We propose four types of political violence against civilians-selective, collateral, categorical, and indiscriminate. Our quantitative analysis of civilian deaths over the course of forty years of the Troubles in Northern Ireland indicates large numbers of killings in three of the four categories by both state and nonstate actors. Illustrating the folly of monocausal, static explanations, these analyses provide strong empirical support for: (1) a wide range of reasons why civilians are killed; (2) variations in the types of political violence against civilians committed by different combatants; and (3) changes over time in the forms of political violence against civilians that dominate contention.

The findings demonstrate the insights provided by a contention-oriented approach. In contrast to popular portrayals of ethnonationalist violence against civilians as primarily, if not exclusively, sectarian, the majority of civilians killed during the Troubles were either targeted because of their behaviors (perceived or actual) or were killed because of their physical proximity to contention or combatants. Several different behaviors resulted in civilians being frequently killed - above all, the perception or the reality that the civilian was directly involved in armed struggle.

Like other types of social movements, armed ethnonationalist movements developed and implemented strategies over the course of contention. These strategies can critically affect levels and forms of violence against civilians. For instance, an end to an all-out offensive by the Provisional Irish Republican Army in the mid-1970s resulted in significant reductions in all forms of political violence against civilians, particularly collateral and categorical forms. As social movement scholars increasingly revisit the subject of strategy, we should apply new insights to understanding political violence.

By affecting the formation and implementation of the strategies of combatants, several other factors influenced the killings of civilians. Surprisingly little scholarly attention has been devoted to the relationship between weapons technologies and forms of terrorism against civilians. The use of indiscriminate weapons was significantly related to multiple forms of political violence against civilians. The findings have important practical implications for security strategies. In particular, when civilians' lives are given higher priority than the lives of security forces (which our analysis above suggests may not always be the case), then security forces are better advised to concentrate their investigative efforts on finding explosives rather than upon finding firearms. While televised displays of seizures of large arms caches plays well with the media and the general public, they put uninvolved civilians more in harm's way if they divert resources away from seizing explosives. The feeling of greater security among the populace generated by these images actually is diametrically opposed to the reality of greater insecurity.

Our analysis adds nuance to the assertion that complicit civilians are more likely to be victims of categorical political violence. As expected, Catholic civilians located in Republican paramilitary strongholds were more likely to be randomly killed by Loyalists and Security Forces than civilians elsewhere. Protestant civilians located in Loyalist paramilitary strongholds, however, were not significantly more likely to be randomly killed by Republicans. 
Moreover, Protestant civilians were less likely to be killed in Republican strongholds. The results underscore the importance of collective identity to explaining political violence against civilians. Whereas neither Loyalists nor Republicans could reasonably expect to form alliances with civilians having opposing ethnonationalist affiliations, Loyalists engaged in categorical violence to a far greater extent than Republicans. The findings are consistent with the more inclusive identity boundaries drawn by Republicans. They also underscore the need for social movement scholars studying the dynamics of contention to pay closer attention to symbolic factors. For peace scholars, the results affirm the importance of identity transformation to the reduction of intergroup violence.

This is not to say that combatants do not influence one another's behaviors. Loyalists and Republicans frequently reciprocated each other's increases and decreases in civilian killings. Both Loyalists and Security Forces negatively sanctioned the Provisional IRA's all-out offensive by significantly increasing categorical violence. The results underscore a recurrent theme in peace and conflict studies, namely how defensive efforts to deter attacks on civilians by opponents can result in a rapid increase in political violence. Conversely, both sets of actors positively sanctioned PIRA ceasefires by decreasing categorical violence. So while combatants can inadvertently reinforce political violence against civilians through their efforts at deterrence, they also have the agency to break the cycle by ending reciprocal violence.

Our findings suggest that the hegemonic political discourse of not negotiating with terrorists can, if implemented as policy, contribute to sustained paramilitary violence against civilians. The first four major initiatives at a negotiated political settlement in Northern Ireland were exclusive of political parties associated with paramilitary organizations. Both Republicans and Loyalists significantly intensified their attacks on civilians during these peace processes. In contrast, Republicans, on the whole, decreased their attacks on civilians during the peace process that resulted in the Belfast Good Friday Agreement-a process that was inclusive of Sinn Féin, the political party supportive of the Irish Republican Army. Moreover, categorical violence by Loyalists did not significantly increase as it had in past peace processes. The results lend compelling quantitative support to an important finding from comparative historical research: peace processes are less likely to succeed if they exclude those who are capable of spoiling the process by attacking civilians.

Similar types of analyses are needed to determine the external validity of the findings for this case. Continuous, longitudinal measures related to other potential sources of political violence against civilians such as high levels of nonviolent protests, inflammatory media coverage, polarized cross-community attitudes, industrial unrest, high levels of residential segregation, and low levels of exogamy were not available in this case, but could be accessible to scholars studying other cases. In particular, we call for closer attention to the relationship between nonviolent protests and armed rebellion and how this relationship influences levels and forms of political violence against civilians. Such studies of contention are badly needed if we are to go beyond impressionistic and polemical studies to gain a nuanced understanding of phenomena that have such negative social consequences.

\section{APPENDIX A: LIST OF HYPOTHESES}

Hypothesis 1: Indiscriminate political violence against civilians will take place the least.

Hypothesis 2: Over the course of a cycle of contention, selective and collateral political violence will constitute large percentages of civilian victims.

Hypothesis 3: Major changes in the strategies of combatants are likely to lead to significant changes in the levels and types of political violence perpetrated against civilians. 
Hypothesis 4: The increased availability of less discriminating weaponry increases all forms of political violence against civilians.

Hypothesis 5: Civilians in areas providing high levels of support for an armed actor are more likely to be victims of categorical political violence.

Hypothesis 6: Combatants with more inclusive collective identities will be less likely to engage in categorical political violence than combatants with more exclusive collective identities.

Hypothesis 7: Major, sustained increases or decreases in political violence against civilians by an armed actor are likely to be reciprocated by opponents.

Hypothesis 8: Categorical political violence increases during peace processes largely exclusive of paramilitary organizations and decreases during peace processes mostly inclusive of paramilitary organizations.

\section{APPENDIX B: \\ GLOSSARY OF CASE-SPECIFIC TERMINOLOGY ${ }^{7}$}

\begin{tabular}{|c|c|}
\hline Term & Definition \\
\hline Loyalists & Militant Unionists \\
\hline Nationalists & Mostly Catholic; favor the reunification of Ireland \\
\hline Northern Ireland & $\begin{array}{l}\text { Six of the thirty-two counties of the island of Ireland that are linked politically } \\
\text { with Great Britain as part of the United Kingdom. The other twenty-six counties } \\
\text { are known as the Republic of Ireland, which was declared a sovereign, } \\
\text { independent, democratic state in the } 1937 \text { constitution and declared a Republic } \\
\text { by act of parliament in } 1949 \text {. }\end{array}$ \\
\hline Partition & $\begin{array}{l}\text { Political separation of Northern Ireland from the rest of Ireland; established } \\
\text { under the Government of Ireland Act of } 1920 \text { and the Anglo-Irish (Irish Free } \\
\text { State) Treaty of } 1921 \text {. }\end{array}$ \\
\hline Republicans & Militant Nationalists \\
\hline Reunification & $\begin{array}{l}\text { Ending the partition of Ireland and returning to the rule of Ireland as one political } \\
\text { unit as had been the case prior to the early } 1920 \text { s. }\end{array}$ \\
\hline Unionists & $\begin{array}{l}\text { Mostly Protestant; favor retaining the existing status of Northern Ireland as part } \\
\text { of the United Kingdom. }\end{array}$ \\
\hline
\end{tabular}

\section{APPENDIX C: \\ DISCUSSION OF REGRESSION DIAGNOSTICS AND REMEDIES ${ }^{8}$}

Where possible, the Breusch-Godfrey test was used to detect serial correlation. Unlike the Durbin Watson statistic, the test detects higher order correlations and can be used on regression models that include lagged endogenous variables (Greene 2000: 540; Ostrom 1990: $65)$. Instances of serial correlation were remedied by performing the Hildreth and Lu procedure for searching for a value of $p$ that minimizes the error sum of squares for transformed equations. The procedure better approximates the maximum likelihood estimator of $p$ (Pindyck and Rubinfeld 1998: 164). Without Hildreth-Lu, various transformation procedures experienced difficulties in converging in cases when the value of $p$ was large. We opted for 
the Prais-Winsten transformation because the Corchrane-Orcutt method negatively affects estimator efficiency by discarding the initial observation in the data set (Greene 2000: 547). The Cook-Weisberg test was used to check for heteroscedasticity. We used a Huber-White sandwich estimator in cases of unequal error variances. Our decision to use this estimator reflects the trend away from weighted least squares and other complex corrective procedures (Greene 2000: 522).

\section{NOTES}

'While the concept of "state terrorism" helps somewhat to correct the imbalance, the disproportionate access of political elites to mass communications means that nonstate actors will likely come to mind first when the term "terrorism" is read or heard.

${ }^{2}$ As with the concept of "terror," the term "collateral damage" forms part of a discourse that legitimates political violence by state actors. We choose to use the term collateral violence instead to highlight the physical harm to humans. The term collateral is retained as it emphasizes the discrepancy between intent and outcome. We disassociate ourselves from the idea that a lack of intent to inflict harm upon civilians exonerates perpetrators from legal and ethical responsibilities to protect civilians.

${ }^{3}$ Jeff Goodwin (2006) uses the terms categorical terrorism and indiscriminate terrorism interchangeably. In this article, we make a distinction between these terms to emphasize that categorical violence is to a certain degree discriminating in that a civilian is targeted based upon their perceived affiliation with a collectivity.

${ }^{4}$ The exception was indiscriminate violence where only the lagged dependent variable was significantly related. The model's lack of predictive power is not surprising given the infrequent and sporadic occurrence of indiscriminate killings (see table 1 and figure 1).

${ }^{5}$ We thank one of the anonymous reviewers for this suggestion.

${ }^{6}$ The percentage for Loyalists includes killings involving collusion with security forces.

${ }^{7}$ Much of this appendix appeared in Maney (2007).

${ }^{8}$ Much of this appendix appeared in Maney (2007).

\section{REFERENCES}

Agnew, Robert. 2010. "A General Strain Theory of Terrorism." Theoretical Criminology 14(2): 131-153. Azam, Jean-Paul. 2006. "On Thugs and Heroes: Why Warlords Victimize Their Own Civilians." Economics of Governance 7(1): 53-73.

Ball, Patrick, Paul Kobrak, and Herbert F. Spirer. n.d. State Violence in Guatemala, 1960-1996: A Quantitative Reflection. Retrieved January 12, 2011 (shr.aaas.org/guatemala/ciidh/qr/english/ index.html).

Benini, Aldo A., and Lawrence H. Moulton. 2004. "Civilian Victims in an Asymmetrical Conflict: Operation Enduring Freedom, Afghanistan." Journal of Peace Research 41(4): 403-22.

Bergesen, Albert J., and Omar Lizardo. 2004. "International Terrorism and the World-System." Sociological Theory 22(1): 38-52.

Bhatt, Chetan. 2010. "The 'British Jihad' and the Curves of Religious Violence." Ethnic and Racial Studies 33(1): 39-59.

Black, Donald. 2004. "The Geometry of Terrorism." Sociological Theory 22(1): 14-25.

Branch, Adam. 2005. "Neither Peace nor Justice: Political Violence and the Peasantry in Northern Uganda, 1986-1998." African Studies Quarterly: The Online Journal of African Studies 8(2): 1-31.

Brubaker, Rogers, and David D. Laitin. 1998. "Ethnic and Nationalist Violence." Annual Review of Sociology 24: 423-52.

Butko, Thomas. 2006. "Terrorism Redefined." Peace Review 18(1): 145-151.

Carr, Caleb. 2003. The Lessons of Terror: A History of Warfare against Civilians, revised edition. New York: Random House.

Cohen, Irwin M., and Raymond R. Corrado. 2005. "State Torture in the Contemporary World." International Journal of Comparative Sociology 46(1/2): 103-131.

Conflict Archive on the Internet. nd. "Draft List of Deaths Related to the Conflict." Retrieved July 2, 2011 (cain.ulst.ac.uk/sutton/).

Crenshaw, Martha. 1981. "The Causes of Terrorism." Comparative Politics 13: 379-99.

Darby, John. 2001. The Effects of Violence on Peace Processes. Washington, DC: U.S. Institute of Peace. 
Darby, John, and Roger MacGinty (eds). 2003. Contemporary Peacemaking: Conflict, Violence, and Peace Processes. New York: Palgrave MacMillan.

Drake, Richard. 2007. "Terrorism and the Consolation of History." Hedgehog Review 9(2): 41-53.

English. Richard. 2002. Armed Struggle: The History of the IRA. Oxford: Oxford University Press.

Froystad, Kathinka. 2009. "Communal Riots in India as a Transitory Form of Political Violence: Three Approaches." Ethnic and Racial Studies 32(3): 442-59.

Gareau, Frederick. H. 2004. State Terrorism and the United States: From Counterinsurgency to the War on Terrorism. Atlanta, GA: Clarity Press.

Gill, Lesley. 2007. "'Right There with You': Coca-Cola, Labor Restructuring and Political Violence in Columbia." Critique of Anthropology 27(3): 235-60.

Goodwin, Jeff. 2006. “A Theory of Categorical Terrorism.” Social Forces 84(4): 2027-46.

Gottschalk, Michel, and Simon Gottschalk. 2004. "Authoritarianism and Pathological Hatred: A Social Psychological Profile of the Middle Eastern Terrorist." The American Sociologist 35(2): 38-59.

Greene, William H. 2000. Econometric Analysis, Fifth edition. Upper Saddle River, NJ: Prentice Hall.

Gross, Michael L. 2009. "Asymmetric War, Symmetrical Intentions: Killing Civilians in Modern Armed Conflict." Global Crime 10(4): 320-36.

Herman, Edward, and Gerry O'Sullivan. 1989. The "Terrorism" Industry: The Experts and Institutions that Shape Our View of Terror. New York: Pantheon.

Horne, John. 2002. "Civilian Populations and Wartime Violence: Towards an Historical Analysis." International Social Science Journal 54(4): 483-90.

Independent Monitoring Commission. 2004-2006. First Twelve Reports of the IMC. London: The Stationery Office.

Kriesberg, Louis. 1998. Constructive Conflicts: From Escalation to Resolution. New York: Rowman \& Littlefield.

LaFree, Gary, and Gary Ackerman. 2009. "The Empirical Study of Terrorism: Social and Legal Research." Annual Review of Law and Social Science 5: 347-74.

Lafree, Gary, Laura Dugan, and Raven Korte. 2009. "The Impact of British Counterterrorist Strategies on Political Violence in Northern Ireland: Comparing Deterrence and Backlash Models." Criminology 47(1): 17-45.

Landis, J. Richard, and Gary G. Koch. 1977. "An Application of Hierarchical Kappa-type Statistics in the Assessment of Majority Agreement among Multiple Observers." Biometrics 33: 363-74.

Maher, Thomas V., and Lindsey Peterson. 2008. "Time and Country Variation in Contentious Politics: Multilevel Modeling of Dissent and Repression.” International Journal of Sociology 38(3): 52-81.

Maney, Gregory M. 2005. "Variations in the Causes of Ethnonationalist Violence: Northern Ireland, 1969-1972." International Journal of Conflict Management 16(1): 70-96.

Maney, Gregory M., Ibtisam Ibrahim, Gareth I. Higgins, and Hanna Herzog. 2006. "The Past's Promise: Lessons from Peace Processes in Northern Ireland and the Middle East." Journal of Peace Research 43(2): 181-200.

Maney, Gregory M., Rachel V. Kutz-Flamenbaum, Deana A. Rohlinger, and Jeff Goodwin (eds). 2012. Strategies and Social Change. Minneapolis: University of Minnesota Press.

McKeown, Michael. 2009. "Remembering": Victims, Survivors and Commemoration. Retrieved July 1, 2010 (cain.ulst.ac.uk/victims/mckeown/index.html).

McKittrick, David, Seamus Kelters, Brian Feeney, and Chris Thornton. 2004. Lost Lives: The Stories of the Men, Women and Children Who Died as a Result of the Northern Ireland Troubles. London: Mainstream Publishing.

Moloney, Ed. 2003. A Secret History of the IRA. New York: W.W. Norton \& Co.

Newman, Edward, and Oliver Richmond (eds). 2006. Challenges to Peacebuilding: Managing Spoilers During Conflict Resolution. New York: United Nations University.

Ostrom, Charles W., Jr. 1990. Time Series Analysis Regression Techniques, 2nd. Newbury Park, CA: Sage.

Pindyck, Robert S., and Daniel L. Rubinfeld. 1998. Econometric Models and Economic Forecasts, Fourth edition. Boston: McGraw-Hill.

Romero, Mauricio. 2000. "Changing Identities and Contested Settings: Regional Elites and the Paramilitaries in Colombia." International Journal of Politics, Culture and Society 14(1): 51-69.

San Juan, E., Jr. 2005. "Terrorism and Revolution: The Struggle for National Democracy and Socialism in the Philippines." Cultural Logic: An Electronic Journal of Marxist Theory and Practice. Retrieved January 12, 2011 (clogic.eserver.org/2005/sanjuan.html).

Senechal de la Roche, Roberta. 1996. "Collective Violence as Social Control." Sociological Forum 11: 97-128. 
Seri, Guillermina. 2008. "Terror, Reconciliation, Redemption: The Politics of Memory in Argentina." Radical Philosophy 147: 8-13.

Sim, Julius, and Chris C. Wright. 2005. "The Kappa Statistic in Reliability Studies: Use, Interpretation, and Sample Size Requirements." Physical Therapy 85: 257-68.

Snow, David A., Sarah A. Soule, and Hanspeter Kriesi. 2004. "Mapping the Terrain." Pp. 1-16 in The Blackwell Companion to Social Movements, edited by David A. Snow, Sarah A. Soule, and Hanspeter Kriesi. New York: Blackwell.

Sommier, Isabelle. 2002. “'Terrorism' as Total Violence?" International Social Science Journal 54(4): 473-81.

Stedman, Stephen John. 1997. "Spoiler Problems in Peace Processes." International Security 22(2): 5-53.

Stem, Jessica. 2003. Terror in the Name of God: Why Religious Militants Kill. New York: Ecco.

Sullivan, Scott. 1998. "From Theory to Practice: The Patterns of Violence in Northern Ireland, 19691994." Irish Political Studies 13: 76-99.

Sutton, Malcolm. 2001. Bear in Mind These Dead: An Index of Deaths from the Conflict in Northern Ireland, 1969-2001, 2nd edition. Belfast: Beyond the Pale.

Taylor, Verta, and Nancy Whittier. 1992. "Collective Identity in Social Movement Communities: Lesbian Feminist Mobilization." Pp. 104-129 in Frontiers in Social Movement Theory, edited by Aldon D. Morris and Carol McClurg Mueller. New Haven, CT: Yale University Press.

Tilly, Charles. 2004. "Terror, Terrorism, Terrorists.” Sociological Theory 22: 5-13.

Ukiwo, Ukoha. 2009. "Violence, Identity Mobilization and the Reimagining of Biafra." Africa Development 34(1): 9-30.

Walzer, Michael. 2004. Arguing about War. New Haven, CT: Yale University Press.

White, Robert. W. 1993. "On Measuring Political Violence: Northern Ireland, 1969 to 1980." American Sociological Review 58: 575-85.

. 2006. Ruairi Ó Brádaigh: The Life and Politics of an Irish Revolutionary. Bloomington: Indiana University Press.

_ 2010. "Structural Identity Theory and the Post-Recruitment Activism of Irish Republicans: Persistence, Disengagement, Splits, and Dissidents in Social Movement Organizations." Social Problems 57(3): 341-70.

Woehrle, Lynn M., Patrick G. Coy, and Gregory M. Maney. 2008. Contesting Patriotism: Culture, Power, and Strategy in the Peace Movement. New York: Rowman \& Littlefield. 